\title{
ПУБЛИКАЦИИ
}

DOI: http://doi.org/10.15688/nav.jvolsu.2018.1.5

UDC 930.26(652):726

LBC 63.48(235.5)-427.1

\section{BURIALS OF THE LATE ANTIQUITY FROM THE BURIAL MOUND MANDESARKA-6}

\author{
Mariya R. Makurova \\ Chelyabinsk State Reserve of History and Culture ARKAIM, Chelyabinsk, Russian Federation \\ Yuriy S. Makurov \\ Chelyabinsk State Reserve of History and Culture ARKAIM, Chelyabinsk, Russian Federation \\ Ilya E. Lyubchanskiy \\ Center for Historical and Cultural Heritage of Chelyabinsk, Chelyabinsk, Russian Federation
}

Evgeniy O. Shimanskiy

Chelyabinsk State University, Chelyabinsk, Russian Federation

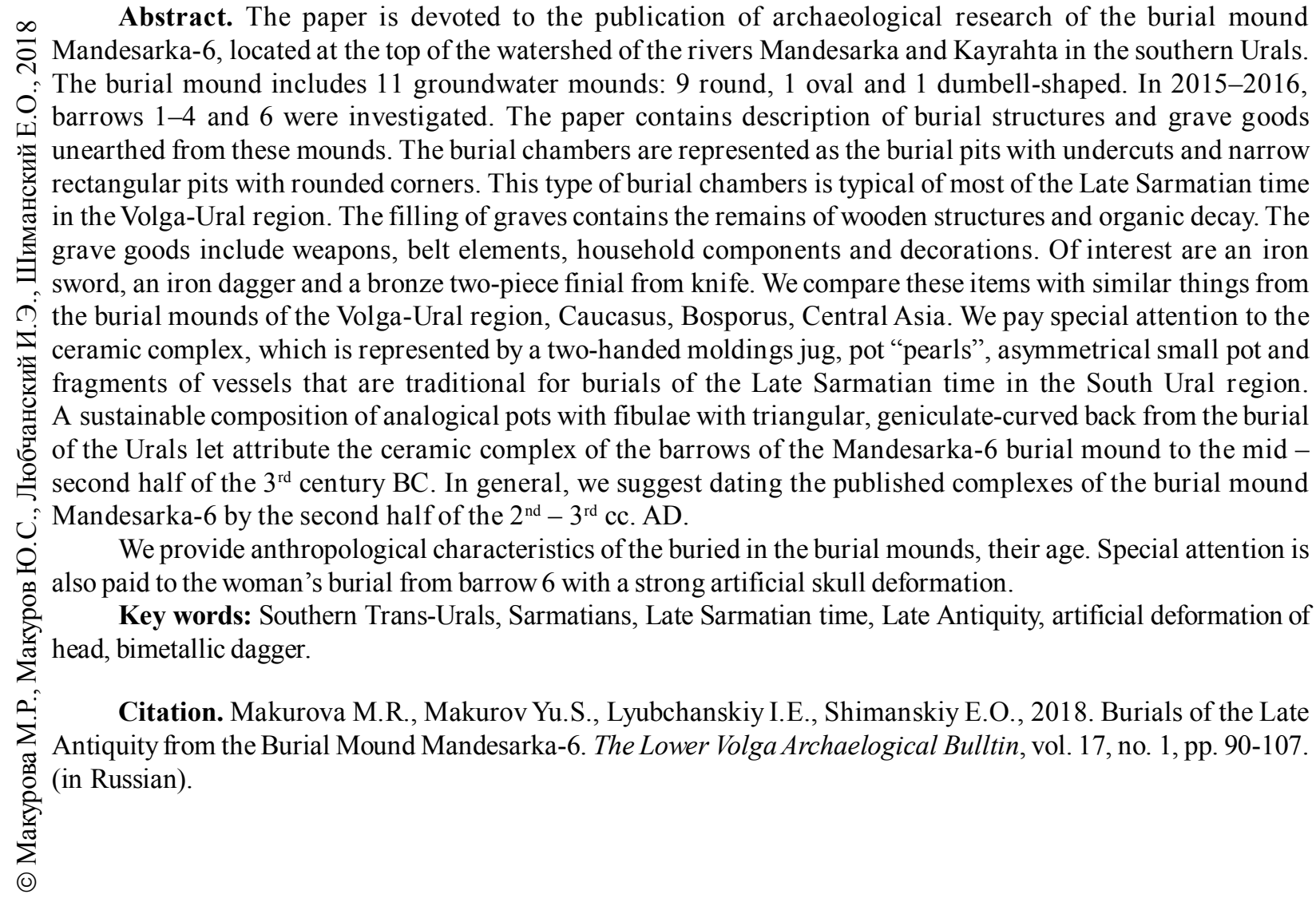




\title{
ПОГРЕБЕНИЯ ЭПОХИ «ПОЗДНЕЙ ДРЕВНОСТИ» КУРГАННОГО МОГИЛЬНИКА МАНДЕСАРКА-6
}

\author{
Мария Раильевна Макурова \\ Челябинский государственный историко-культурный заповедник «Аркаим», \\ г. Челябинск, Российская Федерация \\ Юрий Сергеевич Макуров \\ Челябинский государственный историко-культурный заповедник «Аркаим», \\ г. Челябинск, Российская Федерация
}

Илья Эдуардович Любчанский

Центр историко-культурного наследия г. Челябинска, г. Челябинск, Российская Федерация

Евгений Олегович Шиманский

Челябинский государственный университет, г. Челябинск, Российская Федерация

\begin{abstract}
Аннотация. Статья посвящена публикации археологических исследований курганного могильника Мандесарка-6, расположенного на вершине водораздела рек Мандесарка и Кайрахта в Южном Зауралье. Могильник включает в себя 11 грунтовых насыпей: 9 округлой, 1 овальной и 1 «гантелевидной» формы. В 2015-2016 гг. были исследованы курганы 1-4, 6. Статья содержит описание погребальных сооружений и погребального инвентаря этих раскопанных курганов. Погребальные камеры представлены могильными ямами с подбоями и узкими прямоугольными ямами со скругленными углами. Такой тип погребальных камер характерен для всего позднесарматского времени Волго-Уральского региона. В заполнении могил встречаются остатки деревянных конструкций и органического тлена. Погребальный инвентарь представлен предметами вооружения, элементами ременной гарнитуры, предметами быта и украшениями. Интерес представляют обнаруженные железный меч и железный кинжал, а также бронзовое двусоставное навершие от ножа. Приводятся известные аналогии вещам среди памятников Волго-Уральского региона, Предкавказья, Боспора, Средней Азии. Интересен и керамический комплекс, который представлен двуручным лепным кувшином, горшком с «жемчужинами», асимметричным небольшим горшком и фрагментами сосудов и является традиционным для погребений позднесарматского круга южно-уральского региона. Устойчивое сочетание аналогичных горшков с фибулами, имеющими треугольную, коленчато-изогнутую спинку, из могильников Приуралья позволяет отнести керамический комплекс из курганов могильника Мандесарка-6 к середине - второй половине III в. н.э. В целом для публикуемых комплексов могильника Мандесарка-6 предложена датировка в пределах второй половины II - III в. н.э.

Приводится антропологическая характеристика погребенных в курганах могильника, их возрастной показатель. Особое внимание привлекает погребение женщины из кургана 6 с ярко выраженной искусственной деформацией черепа.
\end{abstract}

Ключевые слова: Южное Зауралье, сарматы, позднесарматское время, эпоха поздней древности, искусственная деформация головы, биметаллический кинжал.

Цитирование. Макурова М. Р., Макуров Ю. С., Любчанский И. Э., Шиманский Е. О., 2018. Погребения эпохи «поздней древности» курганного могильника Мандесарка-6 // Нижневолжский археологический вестник. Т. 17, № 1. С. 90-107.

В полевые сезоны 2015-2016 гг. объединенным отрядом Заповедника «Аркаим» и Челябинского государственного университета исследовался курганный могильник Мандесарка-6 в Кизильском районе Челябинской области (рис. 1,1). Впервые о памятнике стало известно после получения результатов дешифрирования аэрофотоснимков в начале 1990-х гг., которое было проведено И.М. Батаниной. Подготовленное предварительное 
описание и план по результатам анализа аэрофотоснимков вошли в «Археологический атлас Челябинской области» [Зданович и др., 2003, с. 169,170 , рис. 53].

Курганный могильник расположен на вершине водораздела рек Мандесарка и Кайрахта в степной зоне Южного Зауралья. Площадка памятника ровная с небольшим уклоном к югу, в настоящее время окружена небольшими березовыми колками, повреждена проселочной дорогой (рис. 1,2). Могильник представляет собой цепочку грунтовых курганных насыпей, вытянутую по линии 3-В на протяжении 250 м. Визуально зафиксировано 11 насыпей, девять из которых «стандартной» круглой в плане формы. Помимо них обнаружено одно надмогильное сооружение овальных очертаний и еще одна насыпь фигурной «гантелевидной» формы. В обоих случаях длинная ось конструкций ориентирована по оси цепочки могильника, то есть с запада на восток. В центре памятника располагался самый большой курган могильника высотой 0,65 м и диаметром 18 м. Высота остальных насыпей варьировала в пределах 0,2-0,3 м, диаметры круглоплановых насыпей в настоящий момент не превышают 12-13 м. Размеры овальной насыпи $-21 \times 16$ м, высота составляла 0,35 м. «Гантелевидное» сооружение состоит из 2 земляных насыпей диаметром 9,0 м, соединенных слабовыраженным валом. Высота сооружения составляет $0,34 \mathrm{~m}$.

Было исследовано 5 курганов в центральной и восточной части могильника, четыре из которых круглые в плане (№ 1-3, 6), один овальной формы (№ 4).

Курган 1 (рис. 2). Диаметр 18 м, высота 0,65 м. К востоку от кургана располагался каменный наброс современного происхождения. В центральной части кургана, под слоем дерна и гумуса, располагался мощный слой ярко-красной глины толщиной до 0,4-0,45 м, диаметром около 10 м. Нижние участки глиняного слоя имеют ярко выраженные признаки воздействия огня. Слой прокала по всей его площади подстилается прослойкой угля и обугленной древесины. В процессе раскопок были зафиксированы остатки березовых и сосновых плах толщиной до 12-15 см, расположенных хаотично. В северной части подкурганной площадки между прослойкой обугленных плах и погребенной почвой зафиксирован тонкий слой бело-желтой глины мощностью 1-3 см. Возможно, это выкид из могильной ямы. Материк зафиксирован на глубине 95 см от условного «0». Воронка, зафиксированная в центре насыпи кургана до начала раскопок, оказалась грабительской шахтой, которая была заполнена перемешанным грунтом из всех ранее описанных слоев стратиграфии (рис. 2).

В северо-восточном секторе насыпи кургана найден неорнаментированный фрагмент тулова керамического сосуда. Черепок плотный, цвет внешней поверхности - светло-коричневый, внутренней - темно-серый. В формовочной массе визуально видны примеси шамота и органики (травы?) (рис. 5,4). Зачистка на уровне материка выявила очертания могильной и примыкающей к ней грабительской ямы. Могильная яма (основная яма 1a) имела прямоугольные очертания и была ориентирована по линии ССВ-ЮЮЗ. Грабительский вкоп (яма 1б) был расположен к югу от основной ямы и прорезал ее на глубине 0,4 м от уровня материка. У юго-восточного края ямы 16 на уровне материка были расчищены сложенные в кучу кости человека: позвонки, лопатка, берцовые и тазовые кости, фаланги пальцев и фрагменты черепа. Могильная яма имела почти вертикальные стенки. На уровне материка размеры основной ямы составили $2,65 \times 0,95$ м, глубина $-0,95$ м. В центральной и южной частях ямы, в придонном заполнении и на дне, обнаружены кости погребенного: нижняя челюсть, ребра, позвонки, фаланги пальцев и фрагмент бедренной кости. Все кости перемешаны. Не потревоженными остались пяточные кости и несколько фаланг. Это обстоятельство косвенно указывает на изначальную ориентировку погребенного - ногами в южном направлении. Под костями зафиксированы небольшие фрагменты органического тлена, характер которого определить затруднительно. Там же, у южного торца могильной камеры, среди костей найдены коррозированные железные изделия (рис. 6,12,13). Три из шести предметов имеют наилучшую сохранность и представляют собой неглубокие округлые бляшки с бортами-закраинами $(4 \times 4 \times 2$ см). От одной из сторон изделий отходят широкие пластины (ширина 2,5 см), окончания которых не сохранились. Фрагменты 
имеют следы крепления с органическим материалом (предположительно - кожа) с помощью железных штифтов. Еще один фрагмент - тонкая прямоугольная железная пластина, к которой с одной стороны с помощью бронзового штифта прикреплена полоска кожи (рис. 6,6).

Курган 2 (рис. 3,1). Высота насыпи 0,2 м, диаметр 14 м. В центре насыпи - небольшая впадина глубиной 0,1 м, как следствие проседания грунта над могильной ямой. Стратиграфия профилей бровок показала наличие надмогильной площадки диаметром 2,6 м из красно-оранжевого суглинка, расположенной непосредственно над могильной ямой. Мощность площадки над погребенной почвой увеличивалась к центру насыпи с 5 до 17 см, над могильной ямой она линзообразно проседала. В разных частях профилей бровок над суглинистой площадкой зафиксированы фрагментарные следы разведения огня в виде тонких слоев прокаленного гумуса и вкраплений угля.

В центре кургана, с небольшим смещением к югу, на уровне материка, обнаружена могильная яма (рис. 4,1). Могильная яма прямоугольной формы, длинной осью ориентирована по линии С-Ю. Размеры могильной ямы составили 2,8 × 1,2 м. Дно ямы зафиксировано на глубине 0,8 м от уровня материка. На дне ямы, по всему периметру, фиксируется плохо сохранившаяся рамчатая деревянная конструкция. Короткие торцевые плахи лежали поверх длинных продольных плах. При этом последние незначительно выходят за пределы прямоугольных очертаний, образуя подобие «рукояток» носилок. Ширина деревянных элементов конструкции колеблется от 5 до 14 см. За пределами продольных плах и несколько выше их (от 2 до 10 см) у стенок камеры также найдены продольные тонкие (до 5 см) жерди в сильно фрагментированном состоянии. В могильной яме зафиксированы останки органического тлена нескольких типов. Белесый тлен в виде пылевидной субстанции располагался исключительно за пределами рамчатой конструкции и под продольными плахами. На дне, между ног погребенного, располагался черно-желтый волокнистый тлен, а также он фиксировался в районе шейного отдела позвоночника и на черепе, то есть находился под и над покойным. Наконец, тлен черного равномерного окраса находился у правого плеча и правой ноги погребенного.

На дне могильной камеры находился один костяк, уложенный вытянуто на спину, ориентированный головой на С. Руки лежат вдоль туловища, ноги вытянуты, череп раздавлен грунтом.

Погребальный инвентарь найден в пределах деревянной рамы. За черепом расчищен развал керамического сосуда (рис. 5,3). После реставрации сосуд оказался двуручным плоскодонным кувшином, изготовленным вручную со значительной примесью кварца и толченой раковины. Венчик округлый, плавно отогнут наружу, горловина воронкообразная, плавно переходит в широкое тулово. Под верхним креплением ручек по всему периметру расположен лепной валик шириной 0,5-0,6 см. Второй валик расположен выше - в зоне перехода горловины в тулово. На расстоянии 1,5 и 2,1 см ниже от верхней части венчика расположена пара сквозных отверстий диаметром 0,3 см, расположенных на расстоянии 8 см друг от друга. Внешняя поверхность покрыта ангобом бурого цвета. Размеры кувшина: высота - 30,8 см, максимальный диаметр тулова - 21 см, диаметр венчика -12 см, диаметр горла - 9,8 см.

Слева от погребенного располагался железный меч без навершия и перекрестия. Общая длина -81 см, длина рукояти $-7,5$ см. Клинок линзовидный в сечении. Ширина клинка у основания $-4,4$ см, толщина $-1,7$ см. Переход от клинка к рукояти образует тупой угол. Рукоять меча прямоугольная в сечении $(2,1 \times 1,6$ см $)$ и плавно сужается к окончанию. По всей поверхности меча сохранились фрагменты дерева. Вероятно, это могли быть остатки ножен и накладок рукояти (рис. 6,10).

К югу от левой ступни был поставлен черноглиняный тонкостенный лепной керамический плоскодонный сосуд горшечной формы. Черепок плотный буро-красного цвета. Венчик плоский, шейка отогнута, переходит в ярко выраженное плечо, на котором на равном расстоянии расположены шишечки-«жемчужины» диаметром 0,8 см и высотой $0,5 \mathrm{~cm}$. На внутренней поверхности сосуда видны следы нагара черного цвета. Высота сосуда 12 см, максимальный диаметр тулова -15 см, 
диаметр венчика - 12,9 см, диаметр дна 7,8 см (рис. 5,6).

С внешней стороны правой берцовой кости найден железный однолезвийный нож. Общая длина - 13,5 см, ширина клинка 1,2 см. Длина насада $-2,9$ см, ширина -1 см (рис. 6,9).

В погребении были также найдены предметы неясного назначения. В области правой ступни располагался железный предмет плохой сохранности, а у правой плюсны было обнаружено разрушенное деревянное изделие размерами $12 \times 5$ см, которое было покрыто бронзовыми накладками в виде чешуек, фрагменты которых были обнаружены рядом на площади $4 \times 4$ см. Среди чешуек был зафиксирован бронзовый гвоздик. «Между берцовыми костями находился железный предмет длиной 3 см, изготовленный из округлого дрота диаметром 0,5 см, упирающийся во фрагменты деревянного предмета овальной формы (возможно, ложечка)» [Макурова и др., 2016, с. 173].

Антропологические исследования погребенных в курганах 2, 4, 6 были проведены палеоантропологом ИИЯЛ УНЦ РАН А.И. Нечвалодой. Кости скелета из кургана 2 принадлежали молодому мужчине 20-25-ти лет. Череп слабо деформированный. Индивидуальный краниологический комплекс - долихокранный, широко- и высоколицый, клиногнатный с сильно выступающим носом. Череп типологически близок к южным вариантам европеоидной расы [Нечвалода, 2016, с. 46].

Курган 3 (рис. 3,2). Насыпь округлой в плане формы, диаметром 12 м, высотой 0,2 м. Стратиграфия насыпи проста - на погребенной почве лежит выкид красной глины из могильной ямы, который перекрыт гумусным слоем насыпи, поросшей дерном. В южной части насыпи кургана над выкидом из могильной ямы найдены фрагменты керамики, вероятно, от одного сосуда. Часть фрагментов представлена стенками от тулова. На них нанесен орнамент в виде неглубоких прочерченных линий, округлых вдавлений диаметром 0,2 см и «валиков», расходящихся под углом. Один фрагмент - это неорнаментированный венчик с наплывом наружу. Здесь же обнаружена овальная в сечении ручка. Разрозненность и малочисленность фрагментов не по- зволяют провести реконструкцию сосуда (рис. 5,1 ).

Под насыпью кургана находилась одна могильная яма (рис. 4,2). Яма широкой прямоугольной формы. Дно ровное. Зафиксировано на глубине 0,5 м от уровня материка. Стенки ямы вертикальные. Размеры составили в длину 2,6 м, в ширину - 2,0 м. Длинной осью могила ориентирована по линии С3ЮВ. По периметру дно могильной ямы было обложено деревом, максимальная толщина элементов деревянной конструкции составила $0,1 \mathrm{м}$.

На дно могильной ямы, по центру, был уложен один погребенный, вытянуто на спине, ориентированный головой на С3. Кости рук вытянуты вдоль тела, кости ног лежат прямо, череп лицевой частью повернут влево. Погребальный инвентарь представлен украшениями, которые располагались на костяке, и небольшим набором предметов, уложенных в линию справа от покойного. На небольшом расстоянии от правого плеча неполный развал керамического сосуда. Сосуд миниатюрный, лепной, плоскодонный. Из-за отсутствия значительной части фрагментов полная форма и размер не восстанавливаются. Черепок рыхлый, расслаивается, внешняя поверхность красно-серого цвета, на изломе черная. Визуально просматривается примесь шамота, дресвы, органических материалов (рис. 5,5). У правого локтя найден железный однолезвийный нож с прямой спинкой. Общая длина сохранившейся части - $11 \mathrm{~cm}$, максимальная ширина клинка $-1,7$ см, длина - 9,8 см. Переход к насаду под тупым углом, сам насад прямоугольный в сечении, утолщен по сравнению с клинком (рис. 6,8).

У правой кисти, также в отдалении, обнаружено керамическое прясло асимметричнобиконической формы, высота 3 см, максимальный диаметр 4,4 см. Оба основания незначительно вогнуты, как и большая часть боковой поверхности. Диаметры оснований 1,7 и 3,7 см (рис. 6,5). Рядом расчищена плотная меловая субстанция размерами $20 \times 15$ см, которая могла первоначально представлять кусок мела.

Украшения представлены бусинами на кистях и пронизью на шее скелета. По одному комплекту бус располагалось на обеих кистях костяка. Все они однотипны - мелкие, 
непрозрачные, черного цвета из слоистого материала в виде высоких и уплощенных цилиндров. Поверхность гладкая, матовая, размеры от 0,5 × 0,15 до 0,5 ×0,5 см (рис. 6,3,4). На шее погребенного металлическая (железная?) пронизь в виде спирали, закрученной в цилиндр в 3,5 витка. Диаметр - 0,6 см, высота $-0,5$ см (рис. 6,2).

Курган 4 (рис. 3,3). Насыпь овальной формы, вытянута по линии 3С3-ВЮВ, размерами $21 \times 16$ м, высотой 0,35 м. Надмогильное сооружение грунтовое, в бровках над погребенной почвой зафиксирован выкид из могильной ямы в виде красного суглинка, перекрытый серо-коричневым гумусом и дерном. В центре кургана, над выкидом, отмечены небольшие скопления древесного угля. Материк зафиксирован на глубине 0,7 м от условного «0».

Под насыпью, в центре кургана, расчищено одно погребение в подбойной могильной яме (рис. 4,3). Входная яма и подбой ориентированы по линии ЗСЗ-ВЮВ. Размеры ямы на уровне материка составили $2,4 \times 1,35$ м. Дно входной ямы зафиксировано на глубине 1,3 м от уровня материка, подбой располагался в Ю3 продольной стенке. Переход дна к камере подбоя без выраженной ступени. Подбой в длину меньше входной ямы. Стенки входной ямы наклонные. Свод подбоя имеет сферическую форму. Дно входной ямы и подбоя ровное. В подбое расчищены фрагменты деревянной конструкции в виде продольных плах, при этом плаха у западной стенки обожжена. Все дно подбоя покрывал органический тлен желто-черного цвета, аналогичный органике из ямы кургана 2. Помимо этого, органический тлен иного, волокнистого строения, зафиксирован на груди и на правой руке костяка. В погребении находился один костяк, уложенный на спине, вытянуто, головой на С3. Ноги вытянуты, руки вдоль тела, левая слегка согнута в локте.

Покойного сопровождал погребальный инвентарь, находящийся в пределах подбоя. Слева в изголовье располагался лепной асимметричный неорнаментированный керамический сосуд горшечной формы и плоским дном. Внешний край венчика отогнут, на его поверхности бессистемные наплывы. Сосуд красноглиняный, черепок плотный, внешняя поверхность заглажена, имеются следы нагара на внутренней и внешней сторонах. Высота сосуда - 10,5-10,9 см, максимальный диаметр тулова - 11,2 см, диаметр венчика -8 см, дно овальной формы размерами 7,2 × 6,5 см (рис. 5,7).

С внешней стороны левой берцовой кости, ближе к стопе, размещалась железная безщитковая пряжка с округлой рамкой с утолщенной передней и спрямленной задней частью. Сечение рамки округлое, равномерно утолщается в передней части от 0,5 до 0,9 см. Язычок квадратный в сечении $(0,6 \times 0,6$ см), заострен на конце, сохранившаяся длина составляет 1,7 см. Размер пряжки составил 3,6 × 3,7 см (рис. 6,7a).

Еще одна пряжка, аналогичная описанной выше, найдена у левой ступни. Размер рамки - 4,3 × 4 см, толщина - 0,6 см, ширина в задней части - 0,7 см, в передней $-1,3$ см. В сечении рамка сегментовидной формы. Язычок прогнут в средней части. Толщина $(0,4$ см) и ширина $(0,6$ см) язычка примерно равны по всей длине (рис. 6,7б).

С внешней стороны правой берцовой кости, параллельно ноге, острием к ступням, лежал железный кинжал. Общая длина изделия 36,6 см, длина клинка - 27,5 см. Клинок линзовидный в сечении, плавно сужается к острию, его ширина у основания $-3,9$ см. Переход к рукояти в виде крутых плечиков, почти под прямым углом. На кинжале или, возможно, рядом располагался боевой нож, от которого сохранилась биметаллическая рукоять, состоящая из тонкой железной пластины, которая обложена полукруглыми в сечении деревянными накладками и четырьмя расположенными попарно бронзовыми накладками. Все накладки полукруглые в сечении, плотно облегают только железную основу рукояти; на тыльной стороне имеют полости, повторяющие форму изделий. Накладки крепились к рукояти и друг к другу посредством тонких железных заклепок, практически не сохранившихся. Пары накладок отличаются друг от друга. Расположенные у перехода к клинку в виде полуцилиндров $(2,2 \times 1,3 \times 0,5$ см $)$ с одинаковыми выемками на торцах: дугообразными со стороны клинка и треугольными со стороны рукояти. Накладки на окончании рукояти имеют плавное расширение, оформляющее навершие в виде круглой площадки. 
Торцы накладок со стороны клинка имеют треугольную выемку. И кинжал, и нож лежали в ножнах, следы от которых сохранились в виде волокнистого тлена ярко-желтого цвета (рис. 6,1,11).

Антропологическое обследование костей позволило утверждать, что в подбойном погребении был захоронен мужчина в возрасте 25-30 лет. Сильная посмертная фрагментированность черепа позволила лишь констатировать несомненную европеоидность и слабо выраженную прижизненную деформацию [Нечвалода, 2016, с. 46].

Курган 6 (рис. 3,4). Самый восточный погребальный комплекс могильника. Диаметр грунтовой насыпи - 12 м, высота $-0,2$ м.

В северо-восточном секторе насыпи курганы был найден зуб МРС. В западном секторе обнаружен фрагмент лепного керамического сосуда с плоским венчиком, невысокой шейкой, плавно переходящей в тулово, на границе перехода три ногтевых прочерка (рис. 5,2).

Стратиграфическая ситуация аналогична курганам 3 и 4. Небольшие вкрапления угля встречены на уровне выкида из могильной ямы и в ее заполнении. Под насыпью, в центpe, была зафиксирована одна могильная яма. Ее очертания проявились на глубине 0,5 м от условного «0»». Материк фиксировался на этой же глубине. Могильная яма имела неправильную подовальную форму. Длинная ось могильной ямы ориентирована по линии ССВ-ЮЮЗ. Длина ямы составила 1,97 м, ширина в северной части $-0,45$ м, в южной $-0,65$ м. Стенки вертикальные, дно ровное, зафиксировано на глубине 1,37 м от уровня материка.

Могильная яма содержала одно безынвентарное захоронение (рис. 4,4). Костяк лежал вытянуто на спине, головой на ССВ. Руки вытянуты вдоль тела, кисти под тазом, левая ладонью вверх, правая - вниз. Ноги вытянуты и сведены в коленях. Кости скелета сильно стянуты, что может говорить о тугом предпогребальном пеленании тела. Погребенная женщина 35-40 лет. Среди всех раскопанных костяков череп из кургана 6 показывает наибольшую степень деформации. Индивидуальный краниологический комплекс - долихокранный, широко- и высоколицый, клиногнатный европеоидный с умеренно выступающим но- сом, что весьма близко к так называемому приуральскому [Нечвалода, 2016, с. 45-46].

Совокупная характеристика погребального обряда, погребального инвентаря и антропологические характеристики скелетов позволяют отнести исследованные комплексы могильника к начальному этапу периода «поздней древности» [Любчанский, 2013, с. 280; 2017], или к древностям позднесарматской культуры-II-ІІІ вв. н.э. [Мошкова, 2004, с. 37, 38; Малашев, Яблонский, 2008, с. 63].

Погребальный обряд. «Гантелевидные» сооружения, кольцевые и прямоугольные оградки-валы и их вариации - яркая особенность организации погребально-поминального пространства некрополей кочевников Южного Урала второй половины II - III в. н.э. [Мошкова, 1989, с. 191; Боталов, Гуцалов, 2000, с. 122-124; Малашев, 2013, с. 8-9; Любчанский, 2016]. Традиционна для южноуральских могильников этого периода и организация сооружений некрополя в линейно ориентированную композицию, «вписанную» в широтную ландшафтную структуру. Датировку подкрепляют и другие характеристики раскопанных погребальных памятников: небольшого размера грунтовые круглоплановые надмогильные конструкции, основные погребения под индивидуальной насыпью, могильные камеры подбойной и простой прямоугольной формы, одиночное трупоположение усопших вытянуто на спине головой в северный сектор [Скрипкин, 1984 , с. $59,60,65$; Мошкова, 2009, с. 163, 164].

Инвентарь из погребений могильника Мандесарка-6 представлен несколькими категориями археологического материала: предметами вооружения, элементами ременной гарнитуры, предметами быта и украшениями.

К предметам вооружения относятся железный меч из кургана 2 и кинжал из кургана 4. По типологии А.М. Хазанова меч и кинжал относятся к типу 2 мечей и кинжалов без металлических наверший и перекрестия, которые встречаются только в мужских погребениях и являются характерными предметами позднесарматского времени [Хазанов, 1971, с. 15]. С такой трактовкой согласен А.С. Скрипкин, который, так же как и А.М. Хазанов, считает, что мечи с рукоятью-стержнем без металлического навершия и перекрестия и кинжалы с аналогичным устройством становятся обыч- 
ным явлением для позднесарматской культуры [Скрипкин, 1984, с. 84-85].

Интересно решается вопрос хронологии этих предметов вооружения. Оба исследователя сходятся во мнении, что мечи и кинжалы 2-го типа встречаются на протяжении всего позднесарматского времени. Однако, по мнению А.М. Хазанова, «к III в. н.э. они претерпевают некоторые изменения - рукоятьштырь, уже не расширяется книзу, а, как правило, бывает прямой...» [Хазанов, 1971, с. 20]. А.С. Скрипкин в работе 1984 г. писал, что мечи 2-го типа в Нижнем Поволжье в большом количестве появляются с начала II в. н.э. и становятся ведущим типом этой категории вооружения, причем они распространяются уже в готовом виде в основном из районов Прикубанья и Боспора [Скрипкин, 1984, с. 86]. Это же направление распространения мечей и кинжалов из районов Прикубанья, Кавказа, Крыма и Боспора с I-II вв. н.э. предполагает и А.М. Хазанов [Хазанов, 1971, с. 21]. На первый взгляд все логично, но А.М. Хазанов упоминает ряд мечей без металлических наверший и с короткими железными перекрестиями из погребений II-I вв. до н.э. из Кую-Мазарского, Левандакского и Тулхарского могильников, как возможных исходных прототипов мечей 2-го типа [Хазанов, 1971, с. 19-20; Мандельштам, 1966, с. 102, табл. XXXIX]. Очень близок к этим мечам и меч из раскопок у с. Замараево, обнаруженный еще в XIX в. [Зырянов, 1881, т. VII, с. 82], который был датирован П.А. Дмитриевым в пределах І в. н.э. [Дмитриев, 1928, с. 190]. Выясняя хронологию кинжала и меча из могильника Мандесарка-6, следует помнить о находках мечей и кинжалов на некрополях Алтынасар-4 в курганах 330 (кинжал), 365, 408 (мечи). По сопутствующему материалу авторы раскопок датируют их в пределах II-IV вв. н.э., отмечая, что аналогичные длинные мечи без металлического навершия характерны для памятников Приуралья, Поволжья, Средней Азии и Кавказа в указанный отрезок времени [Левина, 1994, с. 240 , рис. $122,2,3$, с. 250 , рис. 132,13$]$. Корреляция сведений о хронологии кинжалов и мечей без металлического навершия и перекрестия указывает на принадлежность кинжала и меча из могильника Мандесарка-6 к кругу памятников, которые датируются II-III вв. н.э. и пополняют коллекцию мечей из южноуральского региона, уже ранее проанализированную одним из авторов [Любчанский 2013, с. $282,291,293 ; 2017$, с. 107-112].

Более важным для уточнения хронологии погребения с кинжалом из кургана 4 выступает бронзовое двусоставное «грибовидное» навершие накладного типа и бронзовая обойма, закрепленная почти у основания рукояти кинжала (или не сохранившегося ножа). Обычно сочетание «грибовидного» навершия и обоймы-«перекрестия» характерно для боевых ножей, которые получают самое широкое распространение только в позднесарматское время и датируются второй половиной II - III в. н.э. [Малашев, Яблонский, 2008, с. 328 , рис. 204; Кривошеев, 2007, с. 66, рис. 1,14,15; Кривошеев, Лукпанова, 2015 , c. 104]. Следовательно, погребение под насыпью кургана 4 могло быть совершено не ранее второй половины II в. н.э. В пользу такой датировки свидетельствуют находки последних лет в южноуральском регионе (мог. Соленый Дол, кург. 4; мог. Таксай I, кург. 4) [Шиманский, 2010, с. 121, рис. 1,13; Кривошеев, Лукпанова, 2015, с. 103, рис. 2,8], которые также датируются в пределах второй половины II - III в. н.э. Основным датирующим материалом в кургане 4 оказываются две небольшие железные пряжки, которые получают широкое распространение в могильниках южноуральского региона в первой половине III в. н.э. [Степи европейской части..., 1989, табл. 8291; Малашев, Яблонский, 2008, с. 51, рис. 202,5-7]. Таким образом, можно говорить, что курган 4 могильника Мандесарка-6, повидимому, может датироваться первой половиной III в. н.э. [Макурова и др., 2016, с. 173].

К предметам ременной гарнитуры, помимо двух железных пряжек из кургана 4, следует отнести шесть железных изделий очень плохой сохранности из кургана 1. Первоначально они рассматривались как железные изделия неясного назначения. Однако после их реставрации ${ }^{1}$ оказалось, что предметы имеют прямое отношение к ременной гарнитуре. Два изделия представляют собой железные полуовальные накладки на узкий ремень, крепившиеся при помощи двух железных штифтов. Сохранившиеся размеры составили $2,5 \times 2,0$ см, с высотой штифтов 3 и 4 мм; 
$2,5 \times 2,5$ см с высотой сохранившегося штифта в 1 мм соответственно (рис. 6,10). Остальные четыре изделия оказались железными подвесками наконечников ремня «ложечковидной» формы, размерами 4,0 × 3,5 см (рис. 6,11). Ближайшая возможная аналогия «ложечковидным» подвескам наконечника ремня происходит из кургана 2 погребения 2 могильника Байрамгулово II на южном берегу Аргазинского водохранилища [Боталов, Полушкин, 1996, c. 182 , рис. 2,33-36]. Известна находка такого изделия и в кургане 43 могильника Покровка10 в Южном Приуралье [Малашев, Яблонский, 2008 , с. 287 , рис. 163,3$]$. Авторами археологический инвентарь этого погребения относится к хронологическому отрезку II-III вв. н.э. По типологии ременной гарнитуры, предложенной В.Ю. Малашевым, обломок бронзового наконечника-подвески из кургана 1 могильника Мандесарка-6 уместно отнести к хронологической группе ІІа (тип наконечника Н3а), которая датируется не ранее второй половины II в. н.э. и не позднее середины III в. н.э. [Малашев, 2000, с. 199]. Таким образом, находки «ложечковидных» подвесок в кургане 1 могильника Мандесарка-6 свидетельствуют о его сооружении не ранее второй половины II в. н.э.

К предметам быта следует отнести биконическое керамическое прясло, два железных ножа и керамику.

Ножи с прямой спинкой и керамические прясла являются массовым материалом в памятниках кочевников волго-уральской степи и существуют на всем его протяжении вплоть до середины V в. н.э. (рис. 6,8,9).

Керамический комплекс, представленный двуручным лепным кувшином, горшком с «жемчужинами», асимметричным небольшим горшком и фрагментами сосудов, традиционен для погребений позднесарматского круга южноуральского региона. Устойчивое сочетание аналогичных горшков с фибулами, имеющими треугольную, коленчато-изогнутую спинку из могильников Приуралья [Малашев, Яблонский, 2008 , с. 67], позволяет отнести керамический комплекс из курганов могильника Мандесарка-6 к середине III в. н.э. (рис. 5).

К категории украшений относятся округлые поперечно сжатые бусы, изготовленные из черных стеклянных трубочек (тип 1 - по Е.М. Алексеевой), получившие широкое распространение в памятниках Северного Причерноморья во II - середине III в. н.э. [Алексеева, 1978, с. 62-63]. Также к украшениям следует отнести обнаруженную в кургане 3 бронзовую пронизь. Как правило, бронзовые пронизки являлись соединительными элементами для ожерелий. Этот элемент украшения встречается повсеместно в женских погребениях южноуральского региона (Покровка-10, курганы 45, 99; Соленый Дол, курган 3) [Малашев, Яблонский, 2008, с. 286, рис. 164,2, c. 304 , рис. 180,1 ; Любчанский, 2017, с. 25 , рис. 7,5]. Они также имеют очень широкое распространение в период второй половины II - III в. н.э. Отсутствие результатов радиоуглеродного датирования не позволяет в настоящий момент говорить об узкой датировке могильника Мандесарка-6, но полученные результаты в ходе полевых и камеральных работ, анализ источника и поиск аналогий позволяет утверждать, что вероятная дата существования могильника будет относиться к рубежу II-III вв. н.э. 
Погребения эпохи «поздней древности» курганного могильника Мандесарка-6

\section{ИЛЛЮСТРАЦИИ}
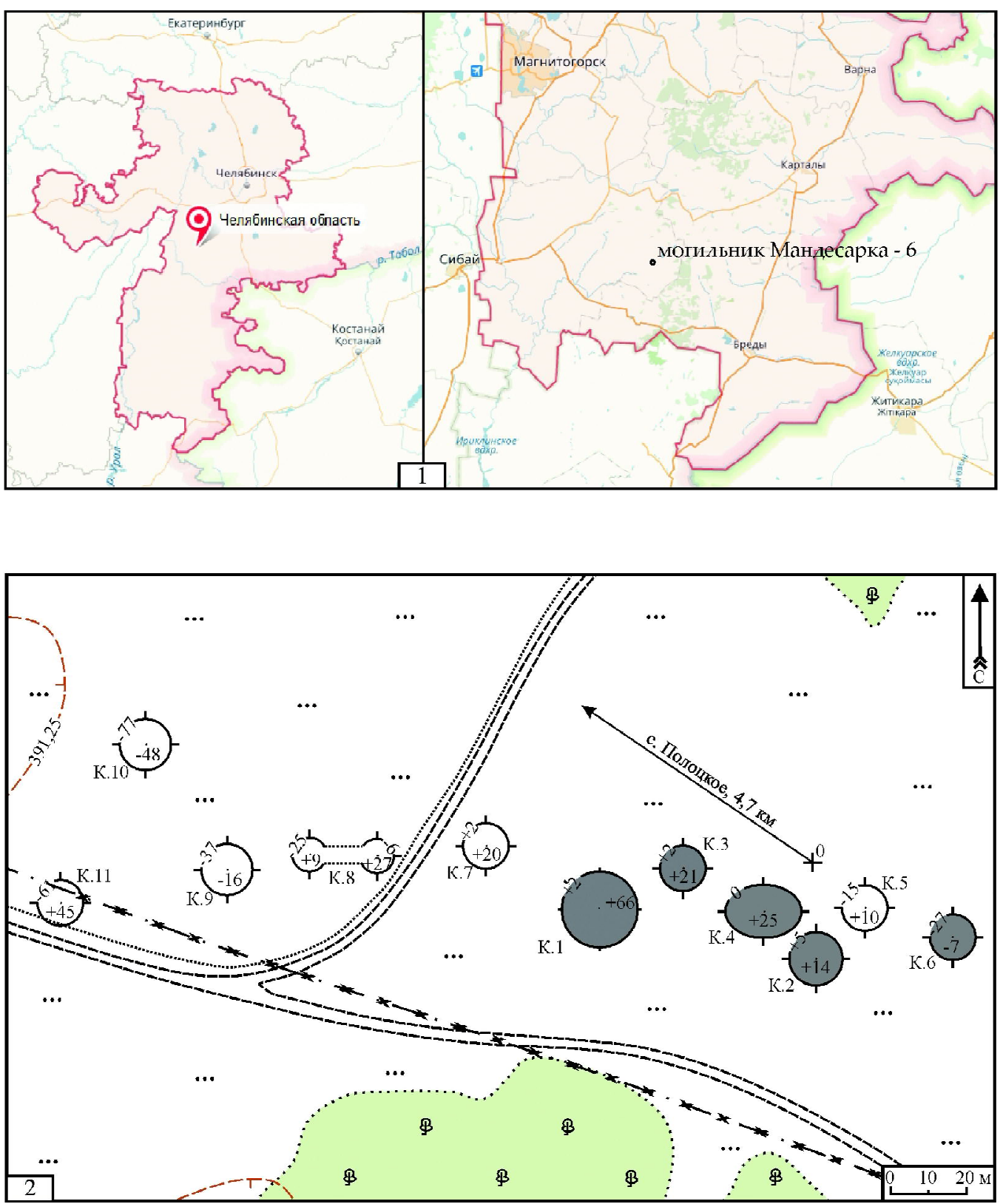

Рис. 1. Могильник Мандесарка-6:

1 - расположение могильника на карте Челябинской области; 2 - план могильника.

Серым цветом выделены курганы, исследованные в 2015 г., штриховкой - курганы, раскопанные в 2016 г.

Fig. 1. Burial mound Mandesarka-6:

1 - location on the map of the Chelyabinsk region; 2 - plan.

The barrows explored in 2015 are highlighted in gray; the barrows excavated in 2016 are highlighted in strokes 


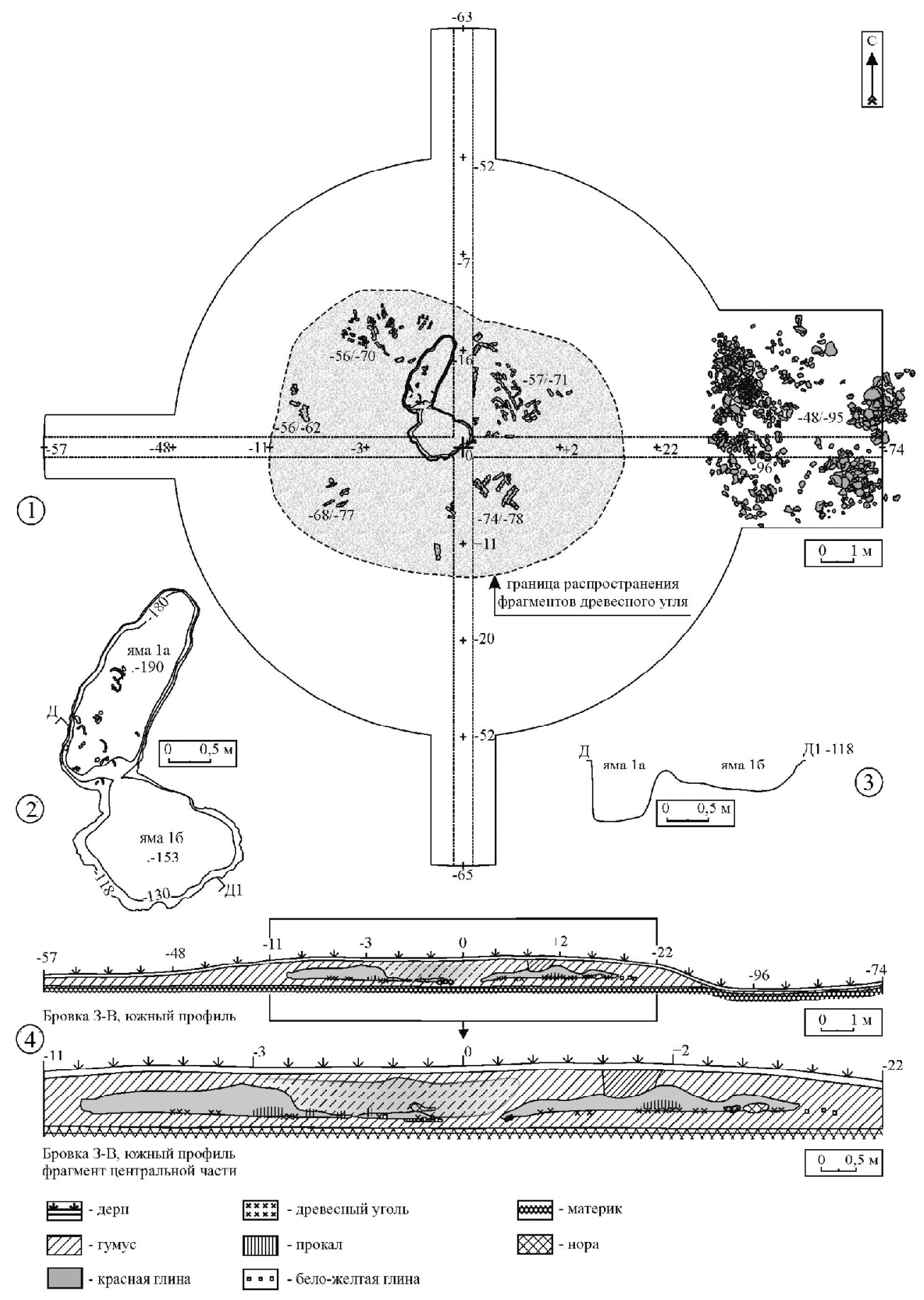

Рис. 2. Могильник Мандесарка-6, курган 1:

1 - план кургана; 2 - план могильной ямы 1; 3 - разрез могильной ямы $1 ; 4$ - бровка 3-В, южный профиль

Fig. 2. Burial mound Mandesarka-6, barrow 1:

1 - barrow plan; 2 - grave 1 plan; 3 - section of grave $1 ; 4$ - west-east baulk, south profile 
Погребения эпохи «поздней древности» курганного могильника Мандесарка-6
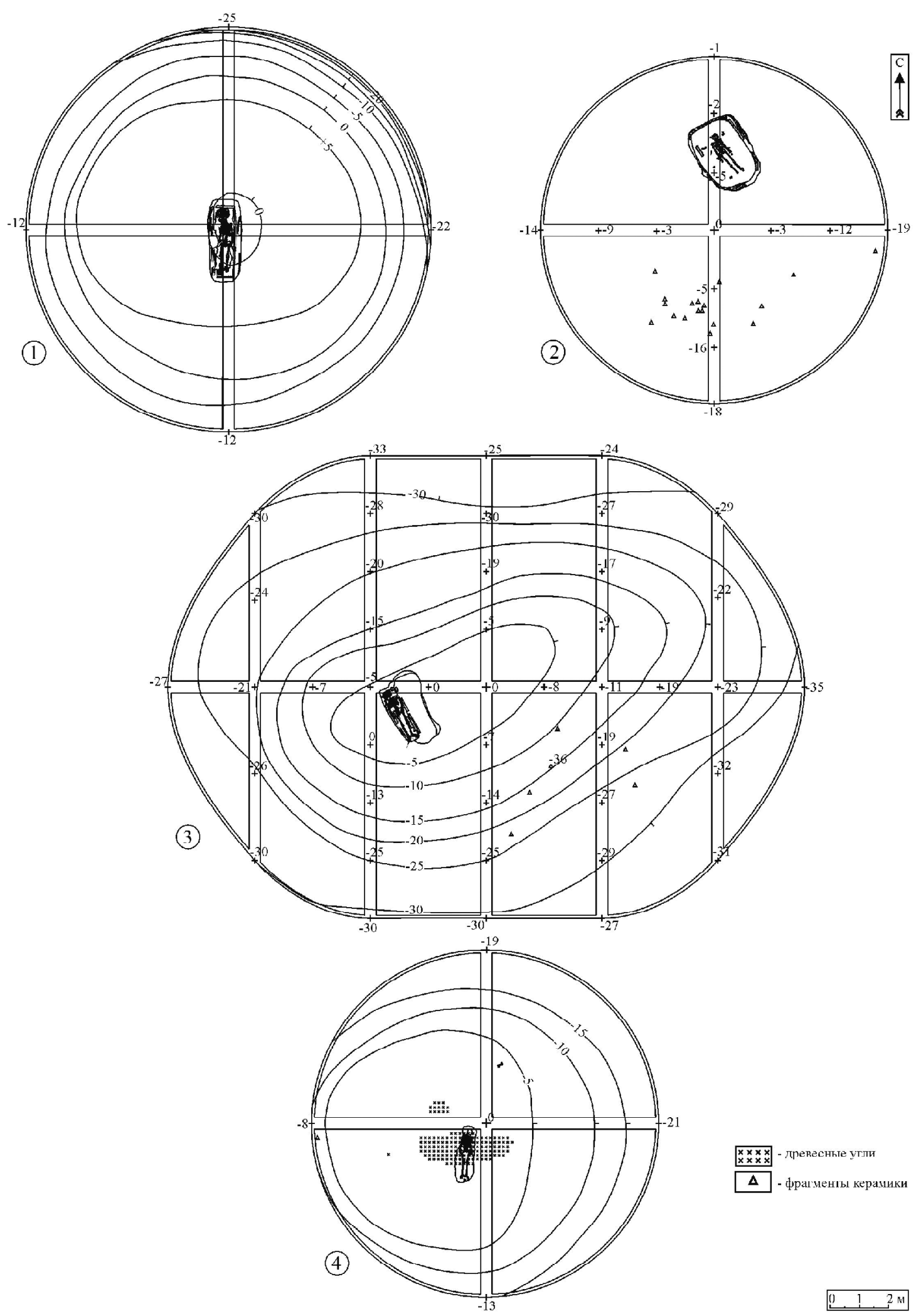

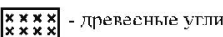

$\Delta$ - фрагиенты керамики

Рис. 3. Могильник Мандесарка-6, планы исследованных курганов:

$$
1 \text { - курган 2; } 2 \text { - курган 3; } 3 \text { - курган 4; } 4 \text { - курган } 6
$$

Fig. 3. Burial mound Mandesarka-6, plans of the investigated barrows:

1 - barrow $2 ; 2$ - barrow $3 ; 3$ - barrow $4 ; 4$ - barrow 6 


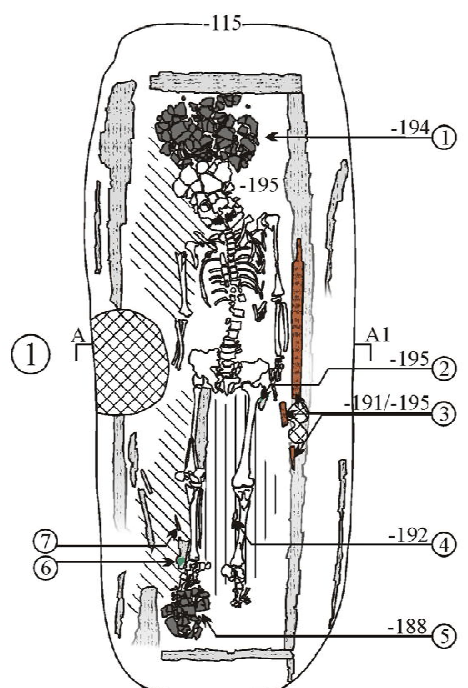

(2)
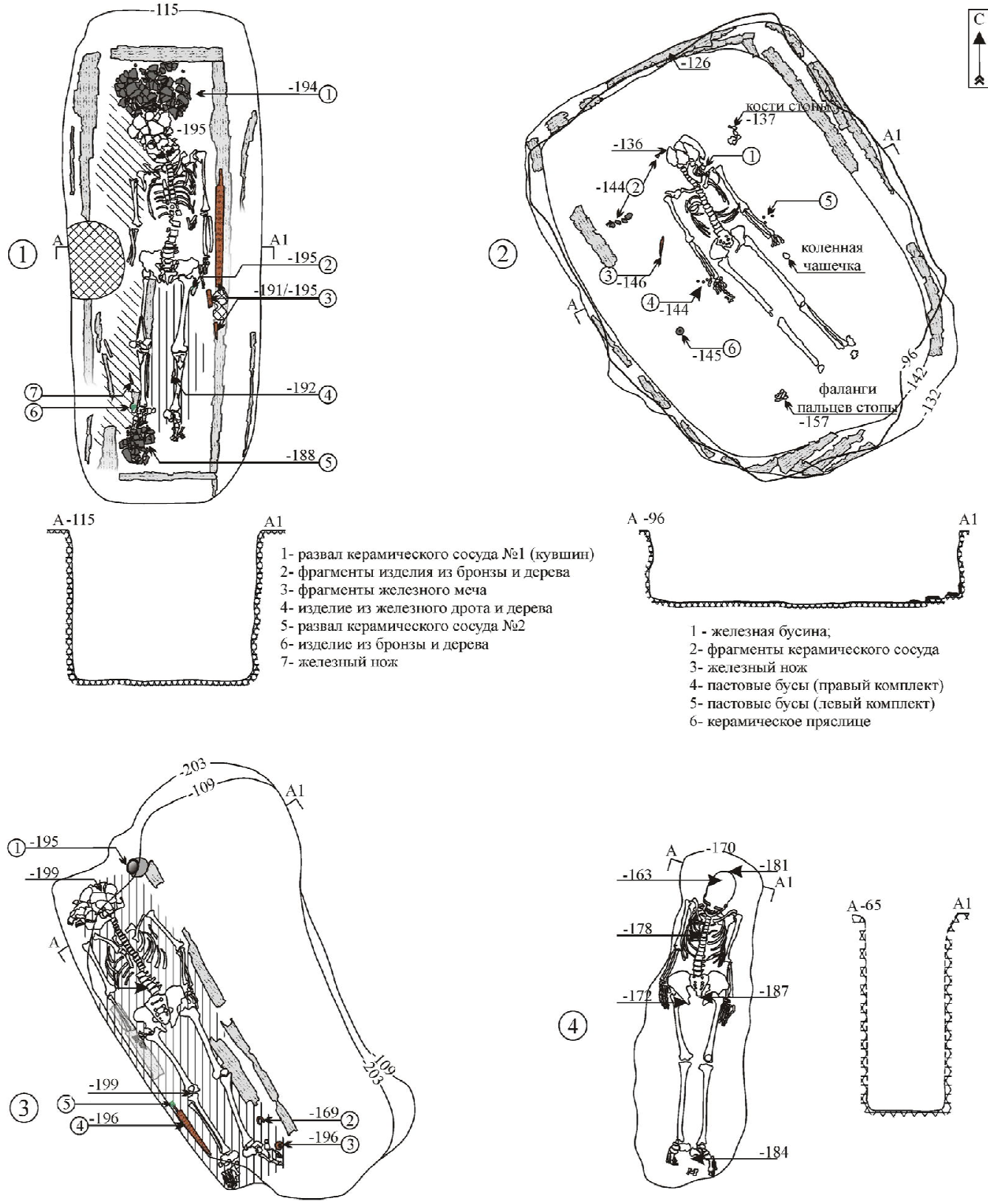

(4)
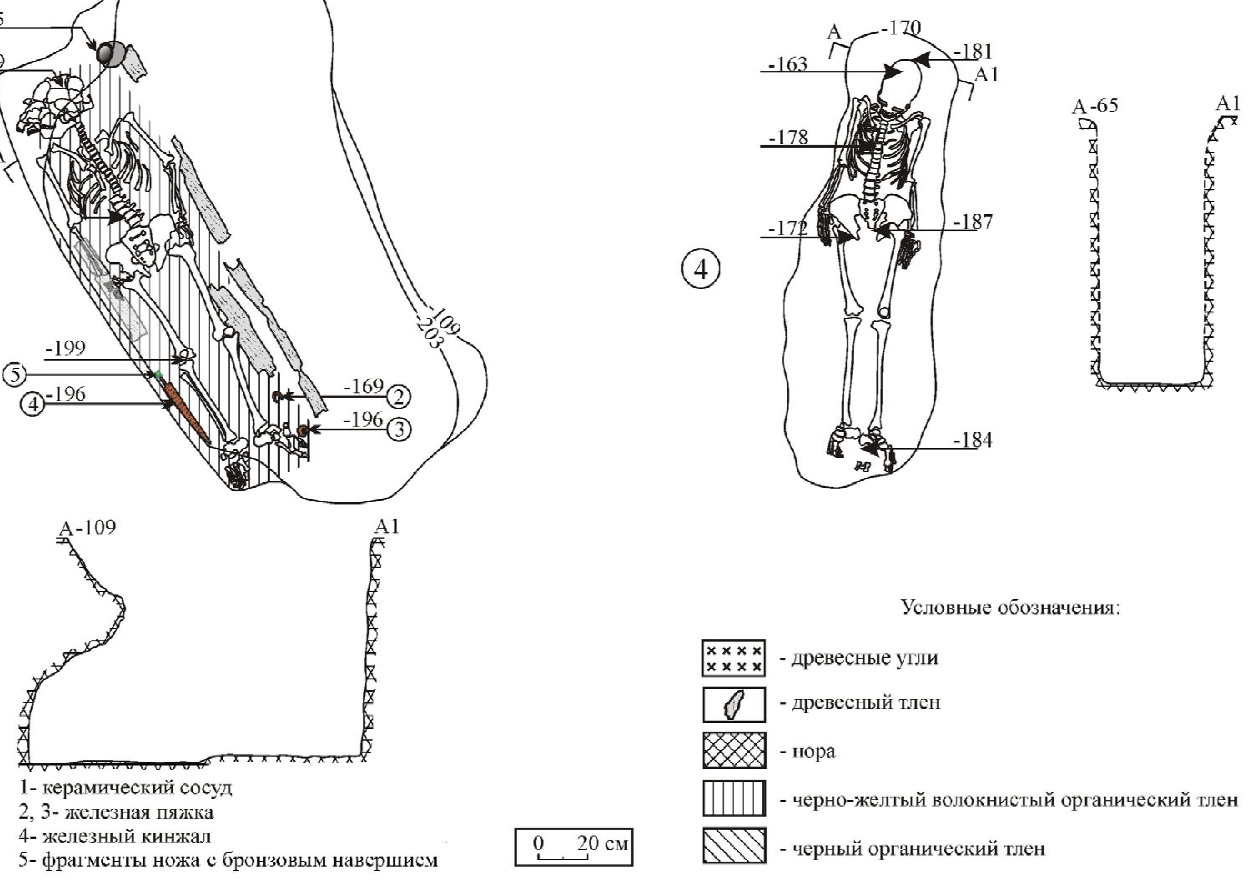

Рис. 4. Могильник Мандесарка-6, планы погребений:

1 - курган 2; 2 - курган 3; 3 - курган 4; 4 - курган 6

Fig. 4. Burial mound Mandesarka-6, plan of burials:

1 - barrow $2 ; 2$ - barrow $3 ; 3$ - barrow 4; 4 - barrow 6 
Погребения эпохи «поздней древности» курганного могильника Мандесарка-6

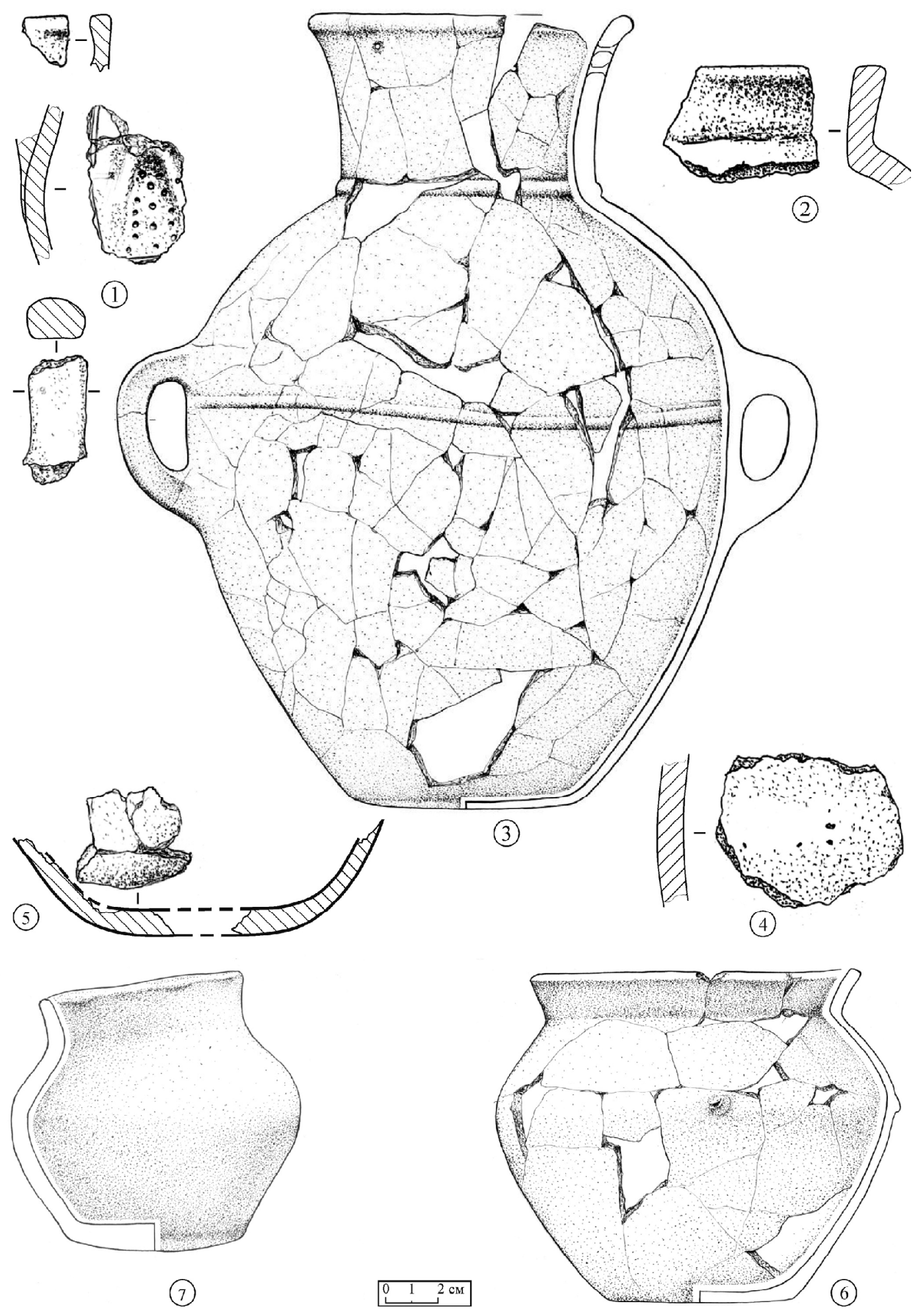

Рис. 5. Могильник Мандесарка-6, керамический комплекс из погребений и насыпей курганов: 1 - курган 3, насыпь; 2 - курган 6, насыпь; 3, 6- курган 2, могильная яма; 4 - курган 1, насыпь; 5 - курган 3; 7 - курган 4

Fig. 5. Burial mound Mandesarka-6, ceramic complex from burials and mounds:

1 - barrow 3 , mound; 2 - barrow 6 , mound; 3, 6 - barrow 2, grave; 4 - barrow 1 , mound; 5 - barrow $3 ; 7$ - barrow 4 
Burials of the Late Antiquity from the Burial Mound Mandesarka-6

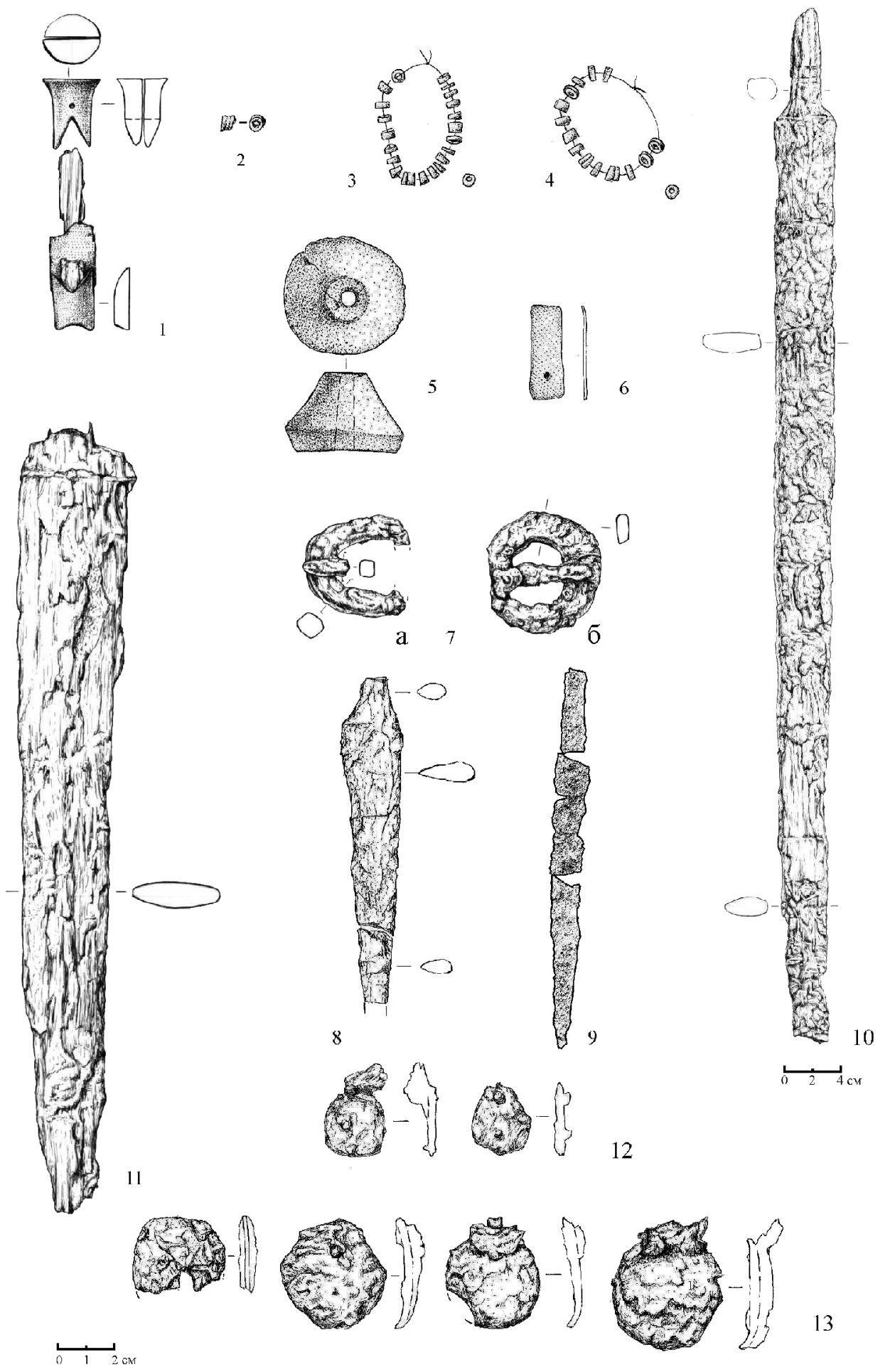

Рис. 6. Могильник Мандесарка-6, погребальный инвентарь:

$2,3,4,5,8$ - курган 3, могильная яма; 6 - курган 1, насыпь; 1, 7a, 76, 11 - курган 4, могильная яма; 9,10 - курган 2, могильная яма; 12,13 - курган 1 , яма $1 \mathrm{a}$;

2, 6 - бронза; 3, 4 - стекло; 5 - керамика; 7-13 - железо; 1 - железо, бронза

Fig. 6. Burial mound Mandesarka-6, grave goods:

2, 3, 4, 5, 8 - barrow 3 , grave; 6 - barrow 1 , mound; $1,7 a, 7 b, 11$ - barrow 4 , grave; 9, 10 - barrow 2, grave; 12,13 - barrow 1 , pit $1 \mathrm{a}$;

2, 6 - bronze; 3, 4 - glass; 5 - ceramics; $7-13$ - iron; 1 - iron, bronze 


\section{ПРИМЕЧАНИЕ}

${ }^{1}$ Приносим благодарность кандидату исторических наук Е.В. Куприяновой за проделанную работу.

\section{СПИСОК ЛИТЕРАТУРЫ}

Алексеева Е. М., 1978. Античные бусы Северного Причерноморья. М. : Наука. 115 с.

Боталов С. Г., Гуцалов С. Ю., 2000. Гунно-сарматы урало-казахстанских степей. Челябинск : Рифей. 266 c.

Боталов С. Г., Полушкин П. А., 1996. Гунно-сарматские памятники Южного Зауралья III-V вв. // Новое в археологии Южного Урала. Челябинск : Рифей. С. 178-193.

Дмитриев П. А., 1928. Мысовские стоянки и курганы // ТСА РАНИОН. Т. IV. С. 189-196.

Зданович Г. Б., Батанина И. М., Левит Н. В., Батанин С. А., 2003. Археологический атлас Челябинской области. Вып. 1. Степь - лесостепь. Кизильский район. Челябинск : Южно-уральское книжное издательство. 240 с.

Зырянов А. Н., 1881. Курганы и городища Шадринского уезда Пермской губернии и находки в них // Заметки УОЛЕ. Т. VII, вып. 3. Екатеринбург. С. 80-92.

Кривошеев М. В., 2007. Вооружение позднесарматского времени Нижнего Поволжья // Вооружение сарматов: региональная типология и хронология : докл. к VI Междунар. конф. «Проблемы сарматской археологии и истории». Челябинск : Изд-во ЮУрГУ. С. 65-70.

Кривошеев М. В., Лукпанова Я. А., 2015. Позднесарматское элитное воинское погребение из Южного Приуралья // Вестник Волгоградского государственного университета. Серия 4, История. Регионоведение. Международные отношения. № 5 (35). С. 98-111.

Левина Л. М., 1994. Джетыасарская культура. Могильники Алтынасар-4 // Низовья Сырдарьи в древности. Вып. 4, ч. 3-4. М. 312 с., ил.

Любчанский И. Э., 2013. Могильник Соленый Дол и его место в культуре кочевников Южного Урала эпохи «поздней древности» // Гуннский форум: проблемы происхождения и идентификации культуры евразийских гуннов : сб. науч. тр. Челябинск : Издат. центр ЮУрГУ. С. 280-297.

Любчанский И. Э., 2016. Архитектоника могильников «поздней древности» Южного Зауралья // Константин Федорович Смирнов и современные проблемы сарматской археологии : материалы IX Междунар. науч. конф. «Проблемы сарматской археологии и истории», посвящ. 100-летию со дня рождения Константина Федоровича Смирнова. Оренбург : Изд-во ОГПУ. C. $157-161$.

Любчанский И. Э., 2017. Курганный могильник Соленый Дол (итоги исследований 2006-2010 годов). Челябинск : АБРИС. 132 с.

Макурова М. Р., Макуров Ю. С., Любчанский И. Э., Шиманский О. Е., 2016. Новый памятник номадов Южного Зауралья Мандесарка-6 // Археологическое наследие Урала: от первых открытий к фундаментальному научному знанию (ХХ Уральское археологическое совещание) : материалы Всерос. (с междунар. участием) науч. конф. Ижевск : Ин-т компьютер. исследований. С. 172-174.

Малашев В. Ю., 2000. Периодизация ременных гарнитур позднесарматского времени // Сарматы и их соседи на Дону : материалы и исследования по археологии Дона. Ростов н/Д : Терpa, 2000. С. 194-232.

Малашев В. Ю., 2013. Позднесарматская культура Южного Приуралья во II-III вв. н.э. : автореф. дис. ... канд. ист. наук. М. 25 с.

Малашев В. Ю., Яблонский Л. Т., 2008. Степное население Южного Приуралья в позднесарматское время: по материалам могильника Покровка10. М. : Вост. лит. 365 с.

Мандельштам А. М., 1966. Кочевники на пути в Индию. М. ; Л. : Наука. 232 с., ил.

Мошкова М. Г., 1989. Позднесарматская культура // Степи европейской части СССР в скифосарматское время. Археология СССР. М. : Наука. С. 191-202.

Мошкова М. Г., 2004. Среднесарматские и позднесарматские памятники на территории Южного Приуралья // Сарматские культуры Евразии: проблемы региональной хронологии : докл. к 5-й Междунар. конф. «Проблемы сарматской археологии и истории». Краснодар. C. 22-44.

Мошкова М. Г., 2009. Статистическая обработка погребальных памятников Азиатской Сарматии. Вып. IV. Позднесарматская культура. М. : Вост. лит. $176 \mathrm{c}$.

Нечвалода А. И., 2016. Люди позднесарматской культуры Южного Урала и Западного Казахстана по данным краниологии и антропологической реконструкции лица по черепу // Южный Урал в межэтническом пространстве культур: традиции и современность : материалы II науч.-практ. конф. Челябинск : АБРИС. C. $42-57$.

Скрипкин А. С., 1984. Нижнее Поволжье в первые века нашей эры. Саратов : Изд-во Сарат. ун-та. $149 \mathrm{c}$. 
Степи европейской части СССР в скифо-сарматское время, 1989 // Археология СССР : в 20-ти т. М. : Наука. 464 с., ил.

Хазанов А. М., 1971. Очерки военного дела сарматов. М. : Наука. 169 с.

Шиманский Е. О., 2010. Могильник Соленый Дол. Вещевой инвентарь (по материалам раскопок 2006-2009 гг.) // У фимский археологический вестник. Вып. 10. Уфа : Гилем, С. 121-126.

\section{REFERENCES}

Alexeeva E.M., 1978. Antique beads of the North Pontic Region. Moscow, Nauka Publ. 115 p. (in Russian).

Botalov S.G., Gutsalov S.Yu., 2000. Hunno-Sarmatian Tribes of the Ural-Kazakhstan Steppes. Chelyabinsk, Rifey Publ. 266 p. (in Russian).

Botalov S.G., Polushkin P.A., 1996. Hunno-Sarmatian pamyatniki Yugnogo Urala. Novoe v archeologii Yugnogo Urala. Chelyabinsk, RIFEI Publ., pp. 178-193. (in Russian).

Dmitriev P.A., 1928. Misovskie stoyanki I kurgani. TCA RANION, vol. IV, pp. 189-196. (in Russian).

Zdanovich G.B., Batanina I.M., Levit N.V., Batanin S.A., 2003. Archaeological Atlas Chelyabinsk Region. Iss. 1. Step'-lesostep'. Kizil'skij rajon. Chelyabinsk, South Ural Publishing House. 240 p. (in Russian).

Ziryanov A.N., 1881. Kurgani i gorodischa Shadrinskogo uezda Permskoi gubernii I nahodki v nih. Zametki UOLE, vol. VII, no. 3, Ekaterinburg, pp. 80-92. (in Russian).

Krivosheev M.V., 2007. Arming of the Late Sarmatian time in the Lower Volga region. The Sarmatians Arming: Regional typology and chronology. Reports for the VI ${ }^{\text {th }}$ international conference "The Problems of the Sarmatian archeology and history». Chelyabinsk, Publishing center South Ural State University, pp. 65-70. (in Russian).

Krivosheev M.V., Lukpanova Ya.A., 2015. Late Sarmatian Elite Military Burial from the Southern Urals. Vestnik Volgogradskogo gosudarstvennogo universiteta, Serija 4, Istorija. Regionovedenie. Mezhdunarodnyie otnoshenija [Science Journal of Volgograd State University. History. Regional Studies. International Relations], vol. 5 (35), pp. 98111. (in Russian).

Levina L.V., 1994. Dzetiasarskaya kultura. Mogilniki Altinasar-4. Nizovyia Sirdarii v drevnosti, vol. 4, chap. 3-4. Moscow. 312 p., il. (in Russian).

Lyubchanskiy I.E., 2013. Solyoniy Dol Burial Site and Its Role in the South Ural Nomadic Culture of the Late Antiquity Epoch. The Hun Forum. Origin and identification problems of the Eurasian Huns culture. Collection of scientific papers. Chelyabinsk, Publishing center South Ural State University, pp. 280297. (in Russian).

Lyubchanskii I.E., 2016. The Ancient Southern TransUrals Architectonic Burial Grounds «Late Antiquity». Konstantin Fedorovich Smirnov $i$ sovremennie problemi sarmatskoi arheologii. Materiali IX Megdunarodnoi nauchnoi konferencii "Problemi sarmatskoi arheologii i istorii”. Orenburg, Orenburg state pedagogical University, pp. 157-161. (in Russian).

Lyubchanskii I.E., 2017. Burial mound of Salt Dol (the results of research from 2006 to 2010). Chelyabinsk, ABRIS Publ. 132 p. (in Russian).

Makurova M.R., Makurov J.S., Lyubchanskii I.E., Szymanskii O.E., 2016. New monument to the nomads of the southern Urals Mandesarka 6. Arheologicyeskoe nasledie Urala: ot pervih otkritiy r fundamentalnomu nauchnomu znaniu (XX Uralskoe arheoljgicheskoe soveschanie): materiali Vseros. (s megdunar. uchastiem) nauch. konf. Izhevsk, Institute of computer science, pp. 172-174. (in Russian).

Malashev V.Yu., 2000. Periodization of Belt Fittings of Late Sarmatian Time. Sarmati i ih sosedi na Donu. Materiali i issledovaniya po arheologii Dona. Rostov-on-don, Terra Publ., pp. 194-232. (in Russian).

Malashev V.Yu., 2013. Late Sarmatian culture of the Southern Urals in the II-III centuries. AD. Cand. hist. sci. abs. diss. Moscow. 25 p. (in Russian).

Malashev V.Yu., Yablonskiy L.T., 2008. Steppe Population of Southern Urals in Late Sarmatian Time. Moscow, Vostochnaya literature Publ. 365 p. (in Russian).

Mandelshtam A.M., 1966. Kochevniki na puti v Indiyu. Moscow, Leningrad, Nauka Publ. 232 p., il. (in Russian).

Moshkova M.G., 1989. Late Sarmatian Culture. Stepi evropeiskoy chasti SSSR v skifo-sarmatskoe vremya. Archeology of USSR. Moscow, Nauka Publ., pp. 191-202. (in Russian).

Moshkova M.G., 2004. Middle Sarmatian and Late Sarmatian Monuments in the Territory of the Southern Urals. Sarmatskie kulturi Evrazii: problemi regionalnoi hronologii: dokladi $k$ 5-i Mezdunar. konf. "Problemi sarmatskoii arheologii i istorii”. Krasnodar, pp. 22-44. (in Russian).

Moshkova M.G., 2009. Statistical Analysis of the Funeral Monuments of the Asian Sarmatia, iss. IV. Late Sarmatian Culture. Moscow, Vostochnaya literature Publ. 176 p. (in Russian). 
Nechvaloda A.I., 2016. People of the Late Sarmatian Culture of the South Urals and Western Kazakhstan According Craniology and Anthropological reconstruction of the Face on the Scull. Jugnii Ural $v$ megetnicheskom prostranstve kultur: tradicii $i$ sovremennost: materiali II nauch.-prakt. konf. Chelyabinsk, ABRIS Publ., pp. 42-57. (in Russian). Skripkin A.S., 1984. Lower Volga Region in First Centuries AD. Saratov, Saratov State university. 149 p. (in Russian).
Stepi evropeiskoi chasti SSSR v skifo-sarmatskoe vremya, 1989. Archeologia SSSR: v 20-ti tomah. Moscow, Nauka Publ. 464 p., il. (in Russian).

Khazanov A.M., 1971. Essays on the Military Affairs of the Sarmatians. Moscow, Nauka Publ. 169 p. (in Russian).

Shimanskii E.O., 2010. The Solyonii Dol Burials Ground and Its Tomb Material. Ufimskiy archeologicheskiy vestnik, iss. 10. Ufa, Gilem Publ., pp. 121-126. (in Russian).

\section{Information about the Authors}

Mariya R. Makurova, Head of Museum Department, Chelyabinsk State Reserve of History and Culture ARKAIM, Chelyabinsk, Voroshilova St., 6, 454014 Chelyabinsk, Russian Federation, center arkaim@mail.ru,rafikova_m@mail.ru.

Yuriy S. Makurov, Head of Department of Reserve Conditions, Chelyabinsk State Reserve of History and Culture ARKAIM, Chelyabinsk, Voroshilova St., 6, 454014 Chelyabinsk, Russian Federation, center_arkaim@mail.ru,ymakurov@yandex.ru.

Ilya E. Lyubchanskiy, Candidate of Sciences (History), Associate Professor, Academic Secretary of the Center for Historical and Cultural Heritage of Chelyabinsk, Svobody St., 60, 454081 Chelyabinsk, Russian Federation, hunns@yandex.ru.

Evgeniy O. Shimanskiy, Lecturer, Department of History of Russia and Foreign Countries, Chelyabinsk State University, Pobedy St., 162v, 454084 Chelyabinsk, Russian Federation, evgenshim@yandex.ru.

\section{Информация об авторах}

Мария Раильевна Макурова, начальник музейного отдела, Челябинский государственный историко-культурный заповедник «Аркаим», ул. Ворошилова, 6, 454014 г. Челябинск, Российская Федерация, center_arkaim@mail.ru, rafikova_m@mail.ru.

Юрий Сергеевич Макуров, начальник отдела заповедного режима, Челябинский государственный историко-культурный заповедник «Аркаим», ул. Ворошилова, 6, 454014 г. Челябинск, Российская Федерация, center_arkaim@mail.ru, ymakurov@yandex.ru.

Илья Эдуардович Любчанский, кандидат исторических наук, доцент, ученый секретарь Центра историко-культурного наследия г. Челябинска, ул. Свободы, 60, 454081 г. Челябинск, Российская Федерация, hunns@yandex.ru.

Евгений Олегович Шиманский, преподаватель кафедры истории России и зарубежных стран, Челябинский государственный университет, просп. Победы, 162в, 454084 г. Челябинск, Российская Федерация, evgenshim@yandex.ru. 